\title{
Broad-based Financial Participation Plans and their Impact on Financial Performance. Evidence from a Dutch Longitudinal Panel. ${ }^{1}$
}

\author{
Geert BRAAM and Erik POUTSMA \\ Institute for Management Research, Nijmegen School of Management \\ Radboud University Nijmegen, PO Box 9108 HK Nijmegen, the Netherlands \\ Tel. +31243613086 / Fax. +31243612379 \\ Correspondence: g.braam@fm.ru.nl
}

\begin{abstract}
This study investigates the relationship between broad-based financial participation plans (which target all employees) and financial performance, using a panel dataset of listed, companies (excluding financial institutions) during the period 1992-2009, comprising 2153 observations. We make a distinction between broad-based profit sharing, share and stock option plans. The panel data allow us to take into account time-lag effects, as profit sharing is usually said to have short-term effects, while share plans and stock options and are intended to have longer term impact. Our results show that broad-based profit sharing and share plans and combinations of these plans are positively related with financial performance when compared with companies without such plans. However, the results are inconsistent for the associations between broad-based stock option plans and financial performance in the longer term. These findings extend the literature on financial participation plans by including different forms of broad-based financial participation and showing that the different forms affect companies' financial performance differently. Our results also support earlier reports in the literature, which suggest that there are important synergies between broad-based profit-sharing and share plans, in terms of a better combination of intrinsic ownership behaviors and extrinsic motivation of employees as well as a stronger focus on collective interest and performance when compared with single plans. Keywords: Financial Performance, Broad-based Profit Sharing, Stock Options, Share Plans, Employee Share Ownership, Panel Study
\end{abstract}

JEL classifications: M12, M52, L25

1 Acknowledgments: The authors thank Hanne Meihuizen for her earlier work (2000) and for starting to develop the dataset, SNPI for financial support and Paul Moors for his research assistance. The authors are also grateful for helpful comments and suggestions provided by the anonymous reviewers. 


\section{Broad-based Financial Participation Plans and their Impact on Financial Performance. Evidence from a Dutch Longitudinal Panel.}

\section{INTRODUCTION}

In this paper we investigate the causal relationship between broad-based financial participation plans designed to target all employees and companies' financial performance by examining variation in financial performance given the presence of financial participation plans. For this reason, we distinguish three forms of financial participation plans, i.e., profit sharing, share plans and stock option plans. We argue that the three plans differ in the way they influence attitudes and behavior relevant to the financial performance of the company. In addition, the plans differ in the way financial performance indicators are targeted in the short and longer term. Profit sharing typically increases extrinsic motivation and influences companies' financial performance in the short term, whereas share ownership increases intrinsic commitment via a sense of ownership and thus influences market indicators of financial performance in the longer term.

Using a longitudinal panel of Dutch listed, non-financial companies during the period 1992-2009, our results indicate that companies that only have broad-based profit-sharing plans, on average, perform better in the short term than those without these plans. The results also show that broad-based share plans are positively associated with market-based performance in the longer term. However, the results are inconsistent for the associations between broad-based option plans and financial performance in the longer term. In addition, the findings indicate that companies that have combinations of broad-based share and profit-sharing plans are likely to perform better financially than those without combined plans. This result suggests that there are important synergies between the plans in terms of a better portfolio for employees and a stronger focus on collective performance than in the case of single plans. One type of plan may not only compensate for the disadvantages of the other plan, but also unleash the performance potential of the other plan (Van der Laan et al. 2010).

This study contributes to the literature on the relationship between broad-based financial participation plans and companies' financial performance in several ways. First, the findings support our expectations that the various participation schemes differently trigger 
attitudes and behaviour relevant for financial performance, resulting in different outcomes. Second, our study is among the first to include different broad-based participation schemes in parallel to empirically assess whether there are synergies between the schemes. The growing body of research on the relationship between broad-based financial participation and financial performance indicates that the adoption of schemes which allow for employee participation through profit sharing, employee share ownership and stock options is often associated with higher levels of productivity. However, they focus mainly on one specific form of broad-based financial participation (e.g. stock options, see Sesil and Kroumova 2007) and do not compare the impact of different forms of financial participation in a single study. An exception is Addison and Belfield (2000), who found that profit sharing has a significant positive effect on a qualitative measure of financial performance in companies, comparing companies with employee share ownership schemes with those where there were no such schemes. In addition, different forms of broad-based financial participation may be designed to achieve different outcomes. For this reason, combining schemes might result in synergy (Bryson and Freeman 2010).

Third, we use multiple indicators of companies' financial performance. Performance variables are usually taken to be a single measure of company performance, such as productivity (Sesil and Lin 2011; Lee 2003). Since a single measure of financial performance is likely not to capture all aspects of financial performance which financial participation contracts are designed to influence (Devers et al. 2007; Trébucq 2004), studying different dimensions of corporate financial performance in parallel may contribute to a better understanding of its relationship with broad-based financial participation and positively influence the robustness of the relationships found.

Fourth, we take causality into account. Most studies are cross-sectional, which is problematic in terms of addressing causality (e.g., the above-mentioned study by Trébucq 2004). Exceptions are the panel studies by Sesil and Lin (2011) and Kato and Morishima (2002). Finally, broad-based financial participation has been mainly investigated in US and UK contexts. In his overview of 70 quantitative employee ownership performance studies, Kaarsemaker (2006) noted that 38 studies were carried out in the USA and 9 in the UK. There has been little systematic study of broad-based financial participation in other countries. As a result, there is a tendency that the results of these studies are translated into universal policy descriptions, largely disregarding local conditions. Analyzing broad-based financial 
participation in alternative institutional settings may improve our understanding of how other factors affect financial participation and its relationship with performance.

The remainder of the article is structured as follows. First, we review related literature and develop hypotheses about the relationship between the different forms of broad-based financial participation and financial performance. Then we describe our research method, our results and tests of robustness. Finally, we draw conclusions, discuss the limitations of our study and suggest directions for further research.

\section{LITERATURE AND HYPOTHESES}

\subsection{LITERATURE REVIEW}

Previous research on the influence of financial participation on organizational outcomes is divided into studies focusing on schemes for top management and those focusing on broadbased plans, for which all employees are eligible. In this study we focus on broad-based plans.

In general, theoretical arguments such as the agency and incentives approach (Jensen and Meckling 1976) are used to explain the impact of narrow and broad-based participation plans on company performance, but there are also alternative theories. The expectancy value theory suggests that employees make extra efforts because they expect to receive extra rewards in due course, i.e. a profit share, increased value of the shares or the chance to favorably exercise the options. In this literature review we mainly focus on alternative theoretical arguments for broad-based plans. We follow Klein (1987), who summarizes various arguments for the impact of broad-based financial participation schemes on the attitude and behavior of employees, and hence, outcomes for the organization. For this reason, she formulates three models.

(1) The impact of extrinsic motivation, in which employees make extra efforts because they expect to receive extra rewards in due course. Although this model relates to the agency theory, much of the literature also refers to the expectancy-valence theory of Vroom (1964). This theory suggests a precondition, namely that, in order to produce extra efforts, employees are informed about achievable targets and told they will receive rewards for hitting these targets (whether a share in profits, share ownership or stock options). 
(2) Commitment impact, also known as instrumental effect. Here, through financial participation both employees and employers share risks and act in the common interest. Interests are aligned by focusing employees' attitudes and behavior on a willingness to participate in strategic decision making, a focus on value creation of the company and profits, as well as on cost-effective working practices.

(3) Ownership impact, also known as the intrinsic motivating effect; by receiving stocks in the company, employees develop a feeling of co-ownership and act accordingly. In this model the mechanism is psychological ownership (Pierce et al. 1991, 2001, 2003). The argument is that ownership changes mindsets in such a way that psychological ownership is developed, which leads to changes in attitudes and behavior such as organizational citizenship behavior and higher productivity. This is expressed in extra efforts to sustain the company and protect it from external threats. It generates ownership behaviors that improve financial performance.

In this study we argue that the various schemes may relate differently to these models. Such schemes may differently affect behavior and be designed to achieve different outcomes. Profit sharing is typically short term and is easier to allocate in cash, which makes the extrinsic motivation impact stronger than in the case of share ownership. Compared with profit-sharing plans, share plans are better able to create feelings of ownership and commitment. Option plans may also generate a commitment effect during the vesting period and may create extrinsic motivation due to the possibility of exercise. Because of these differences, we argue that profit sharing may primarily motivate behavior to increase profits in the next year or two, whereas share plans and stock options can motivate behaviors to improve performance with a longer term pay off, such as increased share value, or at least the intrinsic value of the option before exercise. In addition, there may be important synergy effects on financial performance if companies combine plans. For instance combining profit sharing with share plans may activate extrinsic motivation and commitment and ownership feelings with, in the end, a stronger focus on performance.

The above models discuss individual level mechanisms and the question is how they aggregate to the firm level performance. We cannot fully test this question since we have no combined individual en firm level data, but we have several arguments why these individual level mechanism aggregate to the firm level. First ${ }_{\Perp}$ in this study we are looking at broadbased plans, i.e., all employees are eligible, and not narrow based plans. Also, the financial 
participation plans that are presented here are targeted to collective corporate performance. We assume that the broad-based character in combination with collective performance targets induce cooperative behavior as found especially in the commitment and ownership model. There is common interest and a cooperative focus on value creation of the company and profits, as well as on cost-effective working practices, and on sustaining the company and protect it from external threats._Due to the collective incentive elements workers may engage in anti-shirking behavior through peer pressure, which is an answer to the free rider problem as Kandel and Lazear (1992) argue, with positive effects on collective performance. In fact, research has shown that employees who are engaged in ownership and profit sharing plans show more anti-shirking behavior than employees not participating in these plans (Freeman et al., 2010). Freeman et al. found that employees are most likely to take action against shirkers in workplaces where employees participate in profit sharing, stock options, gain sharing or other forms of ownership. They also show that in workplaces with more anti-shirking behavior co-employees work harder and encourage other employees more, and that the workplace facility is more effective in several dimensions related to productivity and corporate value creation, Next, we formulate our hypotheses.

\subsection{DEVELOPMENT OF HYPOTHESES}

\subsubsection{Broad-based share plans}

Broad-based share plans offer employees an ownership stake. Obviously this relates to the ownership or intrinsic impact in Klein's model. Providing shares to employees may change their mindset in such a way that a sense of psychological ownership is developed. Feelings of co-ownership cause changes in attitudes and behavior such as greater organizational commitment, organizational citizenship behavior and increased productivity. Granting shares $\underline{\text { to employees also means that they share risk. In line with the commitment impact in Klein's }}$ model, employees develop a greater willingness to participate in decision making and to focus on creating market value and working more cost effectively to minimize risk. Offering employees an ownership stake strengthens longer term commitment to the company and alignment of interests. Both models imply that the ownership stake leads to extra effort to sustain the company and protect it from external threats. Such a stake generates ownership behaviors that support financial performance, If employees receive non-voting shares, this
Deleted: and the targeting of

\section{Deleted: It}

Deleted: s

Deleted: profit

Deleted: In the next section

\begin{tabular}{|l|}
\hline Deleted: \\
\hline Deleted: In the Dutch context, \\
\hline Deleted: may \\
\hline Deleted: . Although \\
\hline
\end{tabular}


will not affect the assumed ownership effect, but may influence the commitment effect due to limitations in the participation in decision making.

Several empirical studies support this view (Kaarsemaker 2006; Kaarsemaker and Poutsma 2006; Pendleton 2001; Pendleton et al. 1998). Kaarsemaker (2006) presents an overview of these studies. Among the more than 50 studies that examined the relationship between broad-based share ownership and employee attitudes and behavior, two third noted positive relationships, while the others did not produce any clear results. A USA survey among employees conducted by Freeman et al. (2004) found that employee ownership is a strong predictor of psychological ownership. Wagner et al. (2003) found that ownership is significantly related to psychological ownership. Psychological ownership, in turn, had a significant positive association with ownership behaviors measured by group level sales.

Kaarsemaker (2006) also found that in more than 70 studies where the research focused on performance (with performance indicators such as profit, productivity and return on equity) 48 found positive associations, 16 reported insignificant effects, whereas only 6 found negative associations. Some studies also made more subjective evaluations of relative performance. Most of these studies also found positive associations (Conte and Svejnar 1990; Kruse and Blasi 1997, 2001; Pérotin and Robinson 2003). More specifically, Cin and Smith (2002) found a positive association between employee stock ownership plans (ESOP) and gross value added for two samples of listed companies in South Korea; Pugh et al. (2000) found a positive association between employee ownership and productivity and financial performance (e.g. profit margins, return on assets) in a USA sample; Robinson and Wilson (2006) found a positive relationship between employee share ownership and value added per employee for a UK manufacturing sample. These studies mainly refer to the extrinsic motivation and ownership mechanisms.

Most of the above studies are cross sectional. The few studies that use longitudinal panel data also found positive effects of share plans on performance in the long term (Kruse 1992, 1993; Jones \& Kato 1995; Pugh et al. 2000), referring to the ownership impact and the intrinsic motivation effect. Kruse (1993) found that adoption of employee ownership appeared to lead to increases in value and sales per employee, but these were insignificant. The study by Jones and Kato (1995) on a Japanese sample reveals that employee ownership appears to have a positive effect on value added, although it takes three to four years for these effects to manifest. Similar lag effects are found in longitudinal data from electronics 
companies in Taiwan (Lee 2003). Comparing longitudinal data of ESOP companies in the USA, Pugh et al. (2000) found a small short-term positive effect on profitability but the improvement was not permanent. Possible lag effects of the introduction of these plans are important for our expectations.

In summary, we expect a positive effect of broad-based share plans on companies' financial performance, and in particular on their market-based financial performance because of the close relationship between the expected value of the share plans and stock performance. We expect share ownership plans to have lag effects lasting several years. We formulate hypothesis 1 as follows:

\section{H1 Broad-based share plans are positively associated with market-based indicators of companies' financial performance in the longer term.}

\section{2.2 Broad-based profit-sharing plans}

Broad-based profit sharing is a contribution from the company with limited risk because it has upside potential and no downside potential. This contribution clearly does have potential value in terms of the extrinsic motivation model. Usually the profit share is paid in the short term, i.e., each year.

Its high liquidity makes it a useful tool for incentivizing employees and motivating them extrinsically to increase their efforts. There is no ownership stake involved, which means that profit sharing does not immediately target share value. Indirectly, however, new releases about corporate profits may affect the stock price.

Research results have supported the extrinsic model (Buchko 1992; Gamble et al. 2002), where an increase in expected reward encourages extra effort. The review and metastudies of Doucouliagos (1995) and Kruse and Blasi (1997) found that profit-sharing plans have significant positive effects on productivity. Kruse (1993) found that profit-sharing adoption can produce an increment in productivity that is maintained over time. In a study of a large panel of French companies, Fakhfakh and Pérotin (2000) found that profit sharing significantly increases total factor productivity. However, in spite of the fact that these findings show that profit sharing improves productivity, evidence as to its impact on value creation appears to be rather mixed (Long, 2000). For instance, Poole and Whitfield (1994) 
provide no evidence that profit sharing improves profits or value. However, more recently, using a German panel dataset,

Kraft and Ugarkovic (2006) found that the introduction of profit sharing positively affects profitability as reported by top management. Magnan and St Onge (2005) used a dual cross-sectional/longitudinal (pre-post) design comparing profit-sharing adopters with a control group of companies in the Canadian financial services sector that do not offer profit sharing. They found that the adoption of profit-sharing has a positive impact on asset growth with a lag effect of two years. Most research in this area refers to the extrinsic motivation effects of profit sharing. In summary, we expect that profit sharing will have a positive impact on companies' financial performance indices. We formulate our second hypothesis as follows:

\section{H2 Broad-based profit-sharing plans are positively related with financial} indicators of companies' performance in the short term.

\subsubsection{Broad-based option plans}

In the case of stock options the commitment and extrinsic motivation model will mainly apply. With broad-based option plans companies share the post-grant risk with employees. To minimize risks employees develop a stronger commitment to the organization and are more willing to participate in decision making and focus on value creation, at least during the vesting period. Consistent with Klein's commitment effect, stock option plans are designed to attract, motivate and bind executives and employees to the company. They commit less risk-averse employees who accept that a part of their remuneration lies in the future and is therefore risky (Hall and Murphy 2002).

The expected reward gained through exercising the options creates extrinsic motivation to increase efforts designed to create value. Compared with share plans, option plans may be less risky, but they are also less inclined to generate feelings of ownership. Ownership of shares might occur at the point of exercise of options, but in practice in most cases the acquired shares are sold immediately (Weeden et al. 2001; Heath et al. 1999).

However, stock option plans might be a relatively costly type of remuneration. Since they are risky, a risk premium is expected and required by both management and 
employees. This might be achieved by increasing the number of options to cover the risk they face. In addition, stock options are usually given with certain restrictions. Employees typically must wait a specified vesting period before being allowed to exercise the option. In the Dutch case, for instance, the period before employees are able to exercise options is usually four years. Moreover, if the option expenses have to be disclosed in the profit and loss account, this remuneration might have a negative effect on companies' financial performance.

There are only a few studies that focus on the relationship between broad-based options plans and financial performance. In a UK study, a positive relationship was found between broad-based option plans and productivity, but due to the cross-sectional nature of the study the causal sequence could not be determined (Conyon en Freeman 2001). More indepth studies were carried out at Rutgers University (Blasi et al. 2000; Sesil et al. 2001; Sesil et al. 2002). In these studies of US-based companies, positive relationships are found between broad-based option plans and a series of performance indicators in comparison with companies that have no broad-based plans. The longitudinal study by Sesil et al. (2002) found that companies with stock options had higher total shareholder returns, value added per employee, and the number of patents applied for. Ittner et al. (2002) found that options pay off the most when they are given to all employees. The companies that gave more options to employees had higher-than-average returns to shareholders. By comparison, those that provided top management with more options did no better for their shareholders than the other companies in the sample. In a later panel study, Sesil and Lin (2011) conclude that broad-based stock option plans has substantial impact on productivity. However, this effect appeared to diminish over time. It is suggested that this is due to the infrequent issuing of the share options to all employees. For the more regularly issued executive stock options, the effect does not appear to diminish. A more recent study confirmed the limited effect of broad-based stock options (Aboody et al. 2010). Their findings suggest stock options provide sufficiently large incentive effects to favorably affect companies' performance, but mainly at the executive level and not at the broad-based employee level. They suggest that the incentive effects of options are insufficient to have a meaningful effect on overall company performance. We formulate the following hypothesis: 
H3 Broad-based option plans are positively related with financial indicators

of companies' performance in the in the longer term.

\subsubsection{Synergy between broad-based financial participation plans}

It is important to note that several of the performance studies cited above do not make (or are unable to make) a distinction between different types of plans. That is, studies cannot determine if the effect can be attributed to the particular plan under study, given that other plans may also be in place. However, the existence of a combination of plans may have synergic impacts on performance, because one type of plan may not only compensate for disadvantages of the other plan but can also unleash the performance potential that the other plan might have had (Van der Laan et al. 2010). There are several arguments that show that these plans complement each other and are not substitutes. The three plans differ in the way they influence attitudes and behavior relevant to the financial performance of the company. In addition, the three plans are targeted to different financial performance indicators and differ in the way financial performance indicators are targeted in the short and longer term. Profit sharing typically increases extrinsic motivation and influences financial performance in accounting terms, whereas share ownership increases intrinsic commitment via a sense of ownership and thus influences market indicators of financial performance. Stock options affect the commitment and extrinsic motivation. However, stock option plans are less inclined to generate feelings of ownership. Companies may develop a portfolio of financial participation plans to optimize the performance effects on the short and long term. Another argument for synergy is that the plans differ in their fit to the variety of preferences employees may have regarding these plans. Employees may differ in their assessment as to what extent different financial participation plans motivate them to work harder for the company (Blasi et al. 2010). This can be related to risk aversion and other characteristics, such as position and level of pay. In addition, looking at retention in stock option plans, Pendleton (2005) shows that portfolio diversification is an important determinant of employees retaining shares. Companies may act in terms of portfolio diversification to minimize risks for employees and to offer choices related to employees' preferences. Additionally, employees who retain shares have more alternative, share-based investments than those who sell shares after exercise of the options. The study also reveals 
that those who are motivated to participate in option plans for instrumental involvement reasons keep the shares, whereas those who participate for extrinsic reasons immediately sell their shares. These arguments suggest complementarities of plans, where participating in different plans increases the involvement of employees with a possible ultimate effect on financial performance.

Only a few studies have investigated the interactions between different participation plans. Using UK WERS data, McNabb and Whitfield (1998) found that employee ownership interacts negatively with profit sharing, although the presence of one or the other alone has a positive effect on financial performance. However, Addison and Belfield (2000) found a positive effect of ownership combined with profit sharing on financial performance in UK WERS data. Poutsma and Braam (2012) also found positive associations between combinations of broad-based profit sharing and share plans and corporate financial performance. A study in Japan (Ohkusa and Ohtake 1997) found positive interaction effects on productivity. Robinson \& Wilson (2006) found that a combination of profit sharing and share plans is positively related to higher efficiency, compared with companies with no such plans. However, in a study of listed companies in four European countries, Kalmi et al. (2005) found no interaction effects on an overall measure for performance, whereas the study by Bryson and Freeman (2010) found that the impacts on productivity of what they call 'shared capitalism arrangements' are larger when the company combines several schemes.

Our interaction hypotheses are formulated below. In contrast to our single plan hypotheses, we do not include a time dimension in our interaction hypotheses since the combinations of profit sharing (short term) and share and/or option plans (long term) suggest that the combinations of plans induce performance effects on the short and long term, except for the combination of share plans and options, which is naturally long term.

Additionally, in our robustness test, we also examine the relationships between financial Deleted: However performance and broad-based participation plans with no and other time lags.

Our interaction hypotheses are formulated as follows:

H4a Broad-based profit-sharing plans in combination with broad-based share plans are positively associated with companies' financial performance. H4b Broad-based profit-sharing plans in combination with broad-based option plans are positively associated with companies' financial performance. 


\begin{abstract}
H4c Broad-based share plans in combination with broad-based option plans are positively associated with companies' financial performance.

H4d Combinations of broad-based profit sharing, share and option plans are positively associated with companies' financial performance.
\end{abstract}

\title{
3. RESEARCH METHOD
}

\subsection{Sample}

In order to test our hypotheses, we used a sample of 2153 observations covering an 18-year period (1992-2009) for 195 non-financial companies that are publicly listed on the Euronext Amsterdam Stock Exchange. We excluded financial companies because the nature of accounting-based financial performance measurements in the financial sector is not comparable to those of non-financial companies. Consequently, information about the financial performance of financial companies might lend bias to the results.

We drew the data from a number of sources. First, data on general company information and information about companies' financial performance were collected from the global database Orbis which includes the databases Amadeus and Review and Analysis of Companies in Holland (REACH). Amadeus contains financial information on over 20 million public and private companies in European countries. REACH is a comprehensive database that contains information from more than 3.8 million Dutch companies, including financial, historical and marketing data. Second, data on several forms of broad-based financial participation plans were collected from Company.info, a database containing comprehensive information about more than 2.5 million Dutch companies. Finally, the data on general company information and performance and companies' presence of the different types of financial participation plans were merged, yielding a complete data set.

Table 1 presents descriptive statistics for the sample companies. Panel A shows the distribution of sample companies across industry and size, while Panel B presents that distribution across year and industry. ${ }^{2}$ Among these industry groups manufacturing is well

\footnotetext{
${ }^{2}$ Our sample, which is composed of publicly traded firms operating in a variety of industries, includes 34 twodigit Standard Industrial Classification (SIC) codes. However, because we had less than ten observations for five industries, we reclassified our sample in five main industry groups: manufacturing (20-39), trade (50-59), services excluding ICT (40-49, 70-79 excl. 72-73), ICT (72-73) and mining (10-17).
} 
represented with 1147 observations (54\%), trade with 363 observations (17\%) and services excluding companies focused on information and communication technologies (ICT) with 375 observations (17\%). ICT has 227 observations (10\%), while 2\% are mining companies. Panel B also shows that our panel was unbalanced, with the number of company-year observations varying from 136 (in 1997) to 94 (in 2009).

[Insert Table 1]

\subsection{Variable measurement}

\subsubsection{Dependent variables}

To measure companies' financial performance we used five measures of corporate financial performance since a single measure of corporate financial performance is unlikely to capture all aspects of financial performance which financial participation contracts are intended to influence (Devers et al. 2007). We classified our five measures of corporate financial performance into two groups: accounting and market-based performance indicators Earnings per share (EPS), Shareholders' equity per share (SEPS) and Tobin's Q (TOBIN); the market-based performance indicators Dividend Yield (DY) and Total Shareholder Return (TSR). The argument for using accounting and market-based indicators is that accounting measures can be more directly influenced by top management and employees, whereas market-based measures are generally affected by many factors outside the direct control of top management and employees (Gomez-Meija and Wiseman 1997; Van der Laan et al. 2010). Besides, different financial participation plans may be designed to have different effects.

The accounting and market-based performance indicators Earnings per share and Shareholders' equity per share were calculated using information disclosed in a company's financial statements and information on the number of outstanding shares. Tobin's $Q$ was calculated by dividing the market value of a company by the replacement cost of capital. The market-based performance indicators Dividend Yield and Total Shareholder Return reflect a company's performance on the stock market. The Dividend Yield was calculated as the annual dividend per share divided by the share price at the end of the year (this shows how much a company pays out in dividends each year relative to its share price). The Total Shareholder Return is a measure of stock performance that includes the dividend and the share price appreciation realized in a year, divided by the average share price in the year. 


\subsubsection{Independent variables}

To assess the presence of the different forms of financial participation plans we used dummy variables. Two independent raters with a background in business administration and economics used content analysis to code the information disclosed per company per year. Using data from Company.info, they read the entire contents of the corporate annual reports to assess whether broad-based financial participation plans were present for each year that the company was listed on the stock exchange. More specifically, they assessed the presence of the broad-based share plans, profits sharing plans and/or stock option plans (versus no presence of these broad-based financial participation plans) per company per year. During these content analyses some judgment was used. To minimize potential errors through subjectivity - in the event of differences in judgment between the raters - the best interpretation was discussed in a meeting of the raters and the authors of this paper. In total there were fewer than $2 \%$ differences in judgment, which could easily be resolved.

Table 2 presents the distribution of the sample companies' presence of broad-based share plans, profit-sharing plans and/or stock option plans and combinations of these plans. Panel A shows that the distribution of the participation plans in totals and across industry. It turned out that $5 \%, 6 \%$ and $15 \%$ of the companies had broad-based share, profit sharing and option plans, respectively, whereas $7 \%$ of the companies had at least two types of broadbased financial participation plans simultaneously. In 1450 observations there was no type of broad-based financial participation plan at all. Panel B of Table 2 shows how much overlap there was among the types of plans. Among the companies that had broad-based share plans, $35 \%$ and $21 \%$ combined these plans with broad-based profit sharing or option plans, respectively, while $3 \%$ had broad-based share plans in combination with both broad-based profit sharing and option plans. Table 2, Panel $\mathrm{C}$ shows the number of companies that adopted and dropped the various types of financial participation plans in the sample period. Less than $3 \%$ and $2 \%$ of the companies adopted or dropped broad-based financial participation plans, respectively in the sample period (1992-2009).

[Insert Table 2]

\subsubsection{Control variables}


We included company size, industry and year dummies, and random effects as control variables. The natural logarithm of total assets was included as a proxy for the size of the company. The industry dummies corrected for the variation in the companies' financial performance that was not company-specific. We included the year dummies and firm random effects and incorporated a random component that is a function of time to control for omitted variables, attrition and the fact that we have an unbalanced panel (Wooldridge 2002).

\subsection{Analysis}

Our hypotheses were tested using panel data regression techniques. Such techniques have the advantage of incorporating both the cross-sectional information reflected in the differences between the companies, and information in the time-series or within-subject information reflected in changes within the companies over time (Wooldridge 2002).

To test our hypotheses, we used the following general panel data model:

$$
\begin{aligned}
& \text { PERF }_{i, j, t}=\beta_{0}+\beta_{1} \text { SBB }_{i, t-1}+\beta_{2} \text { PSBB }_{i, t}+\beta_{3} \text { OBB }_{i, t-4}+\beta_{4} \text { PSBB }_{i, t} * \text { SBB }_{i, t-1}+\beta_{5} \text { PSBB }_{i, t} * \text { OBB }_{i, t-4} \\
& +\beta_{6} \text { SBB }_{i, t-1} * \text { OBB }_{i, t-4}+\beta_{7} \text { SBB }_{i, t-1} * \text { PSBB }_{i, t} * \text { OBB }_{i, t-4}+\beta_{8} \text { LNTA }_{i, t}+\beta_{9} \text { INDUSTRY }_{i}+\beta_{10} \text { YEAR }_{t} \\
& +\beta_{11} \text { RE }_{i, t}+\varepsilon_{i, j, t} \\
& \text { where, }
\end{aligned}
$$

$\mathrm{PERF}_{\mathrm{i}, \mathrm{j}, \mathrm{t}}=$ performance of company $\mathrm{i}$ in year $\mathrm{t}$ measured by performance indictor $\mathrm{j}$;

with $\mathrm{j}$ = Earnings per share (EPS); Shareholders' equity per share (SEPS); Tobin's Q (TOBIN); Dividend Yield (DY); Total Shareholder Return (TSR).

$\mathrm{SBB}_{\mathrm{i}, \mathrm{t}-1}=$ dummy variable coded as 1 if company $\mathrm{i}$ has broad-based share plans in year $\mathrm{t}-1$ and 0 otherwise;

$\mathrm{PSBB}_{\mathrm{i}, \mathrm{t}}=$ dummy variable coded as 1 if company $\mathrm{i}$ has broad-based profit-sharing plans in year $t$ and 0 otherwise;

$\mathrm{OBB}_{\mathrm{i}, \mathrm{t}-4}=$ dummy variable coded as 1 if company $\mathrm{i}$ has broad-based option plans in year $\mathrm{t}-4$ and 0 otherwise;

LNTA $_{i, t}=$ company size measured by its natural logarithm of total assets of company $i$ in year $\mathrm{t}$;

INDUSTRY = a vector of industry dummies;

$Y E A R$ = a vector of year dummies;

$R E_{i, t}=$ random effect of company $i$ in year $t$ with a random component that is a function of the firm random effect and time, making the model a random slope model.

In our general model, we lag the effects of broad-based share plans relative to the effects of broad-based profit-sharing plans by one year, since broad-based share plans are expected to have longer term effects on companies' financial performance than broad-based 
profit-sharing plans. For option plans we use a four-year lag. Due to institutional constraints in the Netherlands (e.g., tax regulation; the vesting period is usually four years in order to benefit from tax exemption), broad-based option plans have a relatively long-term payoff. ${ }^{3}$

To address the fact that the effects of the various financial participation plans may differ depending on the existence of other plans, we estimate models including both the direct effects of the plans and their interactions. To compute the interaction terms, we use centered versions of the variables involved. The main effect can be interpreted as the average effect. In addition, the assumptions underlying the regression model were tested for multicollinearity based on Pearson correlations and the variance inflation factors. Variance inflation factors (VIF) were smaller than 2 for each of the independent variables, which indicated the absence of multicollinearity. In addition, in an analysis on the residuals, normality and homoscedasticity were not rejected.

\section{RESULTS}

Table 3 reports the results of the regression analyses for the hypothesized relationships between broad-based share, profit-sharing and option plans, the combinations of broadbased share, profit-sharing plans and/or option plans, and companies' financial performance.

\section{[Insert Table 3]}

Table 3 shows positive and significant associations between broad-based share plans and performance when the performance was measured using the market-based measures Dividend Yield and Total Shareholder Return, after having controlled for variations in companies' financial performance related to the other factors specified in the model. These findings indicate that, among the companies that do not have broad-based profit-sharing and option plans, companies with single broad-based share plans are likely to have better market-based performance in the longer term than companies with no such plans. These results support $\mathrm{H} 1$. They indicate that in the longer term broad coverage and spread of shares among employees positively affect market-based financial performance.

\footnotetext{
${ }^{3}$ In the robustness section, we also examine the relationships between financial performance and broad-based participation plans with no and other lag structures, because the different participation plans might have different effects on the motivation and behavior of executives and employees and the measurement of accounting-based financial performance. The results of the additional sensitivity analyses show that the main results were qualitatively similar when using different time lags for the different participation schemes.
} 
$\mathrm{H} 2$ predicts a positive short-term relationship between broad-based profit-sharing plans and financial indicators of companies' performance. Consistently, the results in Table 3 show that the difference in companies' financial performance between the companies that have single broad-based profit-sharing plans and those that do not have such plans is positive. The relationship between broad-based profit-sharing plans and the financial indicators Earnings per share, Dividend Yield and Total Shareholder Return were also significant, while the relationship with Shareholders' equity per share and Tobin's $Q$ were positive but not significant. These findings provide strong support for $\mathrm{H} 2$, indicating that companies that only have broad-based profit-sharing plans, on average, perform better in the short term than those without these plans. They support the expectation that the adoption of broad-based profit-sharing plans has a relatively direct impact on extrinsic motivation and positively impacts companies' financial performance in the short term.

H3 predicts a positive long-term impact of broad-based option plans on financial indicators of companies' performance. The results in Table 3 show that broad-based option plans were significantly positively associated with Total Shareholder Return. However, contrary to expectations, our findings revealed negative associations between broad-based option plans and the other financial performance measures relative to companies without these plans. The association with Shareholders' equity per share was also significant, while the relationships between broad-based option plans and Earnings per share, Tobin's $Q$ and Dividend yield were negative but not significant. These latter findings indicate that, among the companies that do not have broad-based share and profit-sharing plans, financial performance is lower for the companies with only broad-based option plans than for those without these option plans. On average, companies with single broad-based option plans underperform relative to those without these plans. These results suggest that the marginal costs of implementation and use of broad-based option plans are higher than their marginal financial benefits, which is not what we expected. Consequently, the results do not support H3.

Table 3 also shows interaction effects. These were recorded to test $\mathrm{H} 4 \mathrm{a}-4 \mathrm{~d}$, which predict that the existence of combinations of broad-based financial participation plans may have synergistic impacts on financial performance, since one type of plan may reinforce the advantages of another plan. The findings in Table 3 show significantly positive relationships between combinations of broad-based share and profit-sharing plans and the performance 
measures Shareholders' equity per share and Dividend Yield, while the associations with Earnings per share, Tobin's $Q$ and Total Shareholder Return were also positive but not significant. Consistent with our expectation, these findings provide support for H4a, suggesting that companies that have combinations of broad-based share and profit-sharing plans perform better financially than those without these combined plans. They indicate that the effects of broad-based share plans are higher when profit-sharing plans are present and vice versa. This supports the suggestion that there are important synergies between these plans, in terms of a better portfolio for employees and a stronger focus on collective performance than in the case of single plans. It implies that participation in share and profitsharing plans on a broader scale increases both extrinsic and intrinsic motivation and thus encourages employees to perform better.

However, Table 3 also shows that the extent to which the effects of participation plans on financial performance differ - depending on the existence of other plans - is inconsistent for the subsets of companies that have broad-based profit-sharing plans in combination with broad-based option plans but do not have broad-base share plans (H4b), broad-based share plans and option plans but do not have broad-base profit-sharing plans $(\mathrm{H} 4 \mathrm{c})$, or combinations of all three plans and performance $(\mathrm{H} 4 \mathrm{~d})$. These mixed results show a lack of support for the interaction hypotheses H4b-4d. Except for the combination of broadbased profit-sharing and share plans, our results do not support the expectation that the existence of a combination of broad-based plans may have synergic impacts on financial performance because one type of plan may compensate for disadvantages of the other plan and/or unleash the performance potential that the other plan may have.

\section{ROBUSTNESS TESTS}

In spite of our expectation that profit-sharing plans would motivate behavior to increase profits in the short term, whereas share and option plans can motivate behaviors to improve companies' financial performance in the longer term, it is possible that employees could be motivated to take immediate actions that increase a company's profit or its share price. To check whether our results were sensitive to alternative lag effects on financial performance, Table 4 reports the results of additional regression analyses for the relationships between broad-based share, profit-sharing and option plans, and financial performance when all plans have no lag structures. The results in Table 4 are consistent with the main results in 
Table 3 with regard to the effects of board-based share and profit-sharing plans and combinations of broad-based share and profit-sharing plans on financial performance. They indicate that board-based share and profit-sharing plans and combinations thereof have a positive impact on companies' financial performance both in the short and in the longer term.

However, among the companies that do not have broad-based share and profitsharing plans, Table 4 also reveals mixed results for the associations between broad-based option plans and the accounting and market-based indicators of companies' financial performance in the short term. The associations with EPS, SEPS, DY and TSR were significantly negative, while the association with Tobin's $Q$ was significantly positive. These results indicate that incentive effects occur immediately following the grant of options, even when they have not yet vested. However, the significantly negative association with TSR in Table 4, is inconsistent with the finding in Table 3 which indicates that total shareholder return in the longer term is higher for the companies with only broad-based option plans than for those without these option plans. In addition, the significant positive association with Tobin's $Q$ is inconsistent with the findings in Table 3, which shows a negative but not significant association.

\section{[Insert Table 4]}

Additionally, we examined the relationships between companies' financial performance and broad-based profit-sharing plans with a one-year lag, broad-based share plans with a one- and two-year lag, and broad-based option plans with a three, four and fiveyear lag. Additional sensitivity analysis (unreported) showed that the results were consistent with the main results with regard to the associations between board-based share and profitsharing plans and combinations of broad-based share and profit-sharing plans and the financial indicators of companies' performance when using different time lags for the different forms of financial participation, indicating that the results were qualitatively robust.

We also checked whether the results are robust when we explicitly control for the narrow-based plans, using only the schemes at the executive level as the reference groups. The additional findings (unreported) show that for the broad-based share and profit-sharing plans the results do not change qualitatively when using the different reference groups, suggesting that the results are robust to the inclusion or exclusion firms that do not have 
these participation plans. However, consistent with Aboody et al. (2010), the additional analysis shows mixed results for the difference in expected firm financial performance between the firms that have broad-based and narrow-based option plans. We will explain these findings later.

To check the extent to which our results were sensitive to alternative measures of companies' financial performance, we also examined the relationships between log financial performance and broad-based financial participation plans. Additional analysis (unreported) showed that the results were qualitatively similar for the main results when using the log financial performance measures. Besides, we also carried out a sensitivity analysis on the period of investigation, which covers periods of crisis and includes changes in local and global accounting standards, like the adoption of IFRS in 2005. We compared the analysis with different time frames, like before and after the Dotcom crisis of 2000, and found only minor differences in outcomes. Finally, we checked for reversed causality. For this reason, we ran logistic panel data regression models using the three forms of financial participation plans and their combinations as the dependent variables and one-year lagged financial performance measures as independent variables in combination the control variables. The results (unreported) indicate that reversed causality may be limited at play.

\section{CONCLUSION AND DISCUSSION}

This study assessed the relationship between broad-based profit sharing, share plans and option plans, and companies' financial performance using a panel dataset of non-financial companies listed on the Euronext Amsterdam Stock Exchange for the period of 1992-2009, comprising 2153 observations. Our results show positive relationships between broad-based profit sharing plans and financial performance in the short term, whereas broad-based share plans are positively associated with market-based performance indicators in the longer term. The results also indicate that companies that have combinations of broad-based share and profit-sharing plans are likely to perform better financially than those without combined plans. This finding suggests that there are important synergies between these plans, in terms of a better portfolio for employees and a stronger focus on collective performance than in the case of single plans. One type of plan may not only compensate for disadvantages of the other plan but also unleash the performance potential that the other plan may have. However, the results are inconsistent for the associations between broad-based option plans 
and financial performance in the longer term. When shortening the lag effects we also found significant but mixed results for the associations between broad-based stock options and financial indicators of companies' performance ${ }_{k}$ indicating that incentive effects arise immediately following the grant of options. The mixed results for broad-based stock options are also found in other studies. The study of Aboody et al. (2010) suggests that stock options provide sufficiently large incentive effects to favorably affect companies' performance, but primarily so at the executive level and not at the broad-based employee level. They suggest that the incentive effects of options are insufficient to have a meaningful effect on overall firm profitability. In addition, stock option plans might be a relatively costly type of remuneration. Since they are risky, a risk premium is expected and required by both management and workers. This might be achieved by increasing the number of options to cover the risk they face. Additionally, if the option expenses have to be disclosed in the profit and loss account, this remuneration might have a negative effect on companies' financial performance.

Our main theoretical contribution is that the three plans differ in the way they activate attitudes and behaviour relevant for financial performance of the company. In addition, the plans differ in their design to achieve financial performance in the short and longer term. Profit-sharing typically activates extrinsic motivation and is targeted to accounting measures of financial performance, whereas share ownership activates intrinsic commitment and ownership feelings and is targeted to market-based performance. Apart from option plans, we found support for the hypothesized relationships between broadbased share and profit-sharing plans and financial performance. This is in line with studies by Bryson and Freeman (2010) and Freeman et al. (2010) and Kruse et al. (2010).

The results of the study suggest that different schemes may trigger different outcomes which would not be revealed when using a single overall measure of company performance. The importance to include different performance indicators as well as different compensation elements such as stock options and shares is also mentioned in a recent study of pay for performance of executives (Van der Laan et al. 2010). A portfolio of incentives may be substantial and their inclusion in studies is warranted. The finding that combinations of broad-based profit-sharing and share plans are positively associated with financial performance may have a major impact on considerations of adopting different plans in order to make use of synergy effects. 
A limitation of our study is that we used dummies for the presence of schemes and do not have detailed knowledge to what extent schemes have different pay for performance foci. Follow up research should include more detailed account of plans. We were also not able to include other important indicators of coverage such as the exact participation rate and the proportion of value covered by the schemes (Westphal and Zajac, 1998). Further research should take these into account. The impacts of the three models may be greater when the amounts are more substantial (relative to income for instance). Research consistently shows that the positive impact of financial participation plans on several organizational outcome indicators is higher if the participation is broader. This relationship is stronger in the case of broader coverage and spread of the profit and shares among employees (Kalmi et al. 2005). The study by Kruse et al. (2010) used a measure of what they call overall shared capitalism score based on how much ownership employees had in the company and how much they shared in profits and stock options. Based on the US national General Social Survey they found that in companies with higher scores employees were more committed to their company, are more willing to work harder, make more suggestions, and have better fixed pay and working conditions than employees in companies with lower scores. Apart from the impacts that are activated by more substantial plans, another mechanism may account for the effect of broader coverage, i.e., the perception of equity and distributive justice (Adams 1963, 1965). Offering broad-based plans may signal to employees that they share in the surplus and that not only limited numbers of personnel may reap the benefits. Narrow-based plans in the company may develop feelings of inequity, which can lead to perceptions of relative deprivation and inequity (Sweeney et al. 1990), which can reduce the motivation to behave collaboratively (Pfeffer 2005).

This study is the first longitudinal study that analyses the relationship between broad-based financial participation and financial performance over such a long period of 18 years. We used lag effects with optimal results to approach causality and found a substantial pattern of causality. The period includes changes in accounting standards and covers periods of crises. In order to approach causality we compared the analysis with different time frames, and found only minor differences in outcomes. However, to make sure that we cover causality we need more instrumental variables included such as exact initiating dates of plans and possible renewal of plans. 
In addition, this study is among the first studies of the relationship between broadbased financial participation and corporate financial performance for the Netherlands. The few other longitudinal studies focused mainly on executive compensation and with a shorter time frame (Van der Laan et al. 2010; Duffhues and Kabir 2008; Otten et al. 2008). Compared with the longer tradition in the USA and the UK, broad-based financial participation became popular in the Netherlands late 1990ties and after 2000. The fact that this panel study in the Netherlands confirms much of results of the US/UK studies increases the external validity of the relationship between financial participation and performance. However, the Dutch study is still a study in one context, with one specific culture and institutional setting which may limit the generalizability of our findings. Further research could benefit from examining the relationship between financial participation plans and financial performance by using larger international panel data samples including public and private companies and both relative and absolute measures of corporate performance to provide greater insight into the external validity of the findings. In addition, national differences in pay structure call for research into the effect of governance systems and industrial relations on financial participation (Poutsma 2001). It calls also for other variable compensation elements not included in this study such as individually-related performance pay and bonuses, which gained much more prominence in European companies. There may be important tradeoffs between variable pay components also due to changing (tax) legislation and conventions.

Implications of this study for policy are twofold. For employers, this study suggests consideration of the use of schemes for all employees instead of only for the top. At the same time it suggests that we have to consider different types of schemes with different targeted outcomes and it may be that companies should think of the best fit between financial participation plans. For policy makers the study suggests to consider carefully any change in (tax) regulation of compensation elements. The recent financial crisis has led to a call for mitigation and regulation of financial participation, mainly for top management. Although policy makers may try to develop measures to prevent and control greed, they may not be able to capture the details of compensation portfolios and possibilities of tradeoffs that may occur for all employee plans. Any regulation targeted to excesses in the top may also have the unintended consequences of limiting the more democratic and more equality type of financial participation for all. 


\section{REFERENCES}

Aboody, D., Bastian Johnson, N. \& Kasznik, R. (2010). Employee stock options and future firm performance: Evidence from option repricings. Journal of Accounting and Economics, 50, 74-92.

Adams, J. S. 1963. Toward an understanding of inequity. Journal of Abnormal and Social Psychology, 67: 422-436.

Adams, J. S. 1965. Inequity in social exchange. In: Berkowitz, L. (Ed.), Advances in experimental social psychology, New York: N. Y. A. Press, 267-299.

Addison, J.T. \& Belfield, C.R. (2000). The impact of financial participation and employee involvement on financial performance: a re-estimation using 1998 WERS. Scottish Journal of Political Economy, 47, 571-583.

Blasi, J.R., Kruse, D.L., Sesil, J.C., Kroumova, M. \& Carberry, E. (2000). Stock Options, Corporate Performance and Organizational Change. Oakland, Ca.: National Center for Employee Ownership.

Blasi, J.R., Kruse, D.L. \& Markowitz, H.M. (2010). Risk and Lack of Diversification under Employee Ownership and Shared Capitalism. In: Kruse, D.L., Freeman, R.B. \& Blasi, J.R. (Eds), Shared Capitalism at Work: Employee Ownership, Profit and Gain Sharing, and Broad-based Stock Options, Chicago: University of Chicago Press: 105 - 136.

Bryson, A. \& Freeman, R.B. (2010). How Does Shared Capitalism Affect Economic Performance in the United Kingdom? In: Kruse, D.L., Freeman, R.B. \& Blasi, J.R. (Eds), Shared Capitalism at Work: Employee Ownership, Profit and Gain Sharing, and Broad-based Stock Options, Chicago: University of Chicago Press, $201-224$.

Buchko, A. A. (1992). Employee ownership, attitudes, and turnover: An empirical assessment. Human Relations, 45(7), 711-733.

Cin, B. \& Smith, S.C. (2002). Employee stock ownership and participation in South Korea: incidence, productivity effects, and prospects. Review of Development Economics, 6(2): 263-283.

Conte, M. \& Svenjar (1990). The performance effects of employee ownership plans. In: Blinder, A. Paying for Productivity: a Look at the Evidence, Washington DC: Brookings Institution.

Conyon M.J. \& Freeman, R.B. (2001). Shared modes of compensation and firm performance: UK evidence, NBER working paper series.

Devers, C.E., Cannella, A.A., Reilly, G.P. \& Yoder, M.E. (2007). Executive compensation: A multidisciplinary review of recent developments. Journal of Management, 33, 1016-1072.

Doucouliagos, C. (1995). Worker participation and productivity in labor-managed and participatory capitalist firms: A meta-analysis. Industrial and Labor Relations Review, 49, 1, pp 58-78.

Duffhues, P.J.W. \& Kabir, R. (2008). Is the pay-performance relationship always positive? Evidence from the Netherlands. Journal of Multinational Financial Management, 18, 45-60.

Fakhfakh, F. \& Pérotin, V. (2000). The effects of profit-sharing schemes on enterprise performance in France, Economic Analysis, 3, 93- 111.

Freeman, R.B., Kruse, D.J. \& Blasi, J.R. (2010). Worker Responses to Shirking under Shared Capitalism. In: Kruse, D.L., Freeman, R.B. \& Blasi, J.R. (Eds), Shared Capitalism at Work: Employee Ownership, Profit and Gain Sharing, and Broad-based Stock Options, Chicago: University of Chicago Press, 77103.

Freeman, R.B., Kruse, D. \& Blasi, J.R. (2004). Monitoring colleagues at work: profit sharing, employee ownbership, broad-based stock options and workplace perfromance in the United States. NBER paper. Discussion Paper No 647. August 2004. London: Center for Economic Performance.

Gamble, J.E., Culpepper, R. \& Blubaugh, M.G. (2002). ESOPs and employee attitudes: the importance of empowerment and financial value. Personnel review, 31(1-2), 9-26.

Gomez-Mejia, L.R. \& Wiseman, R.M. (1997). Reframing executive compensation: An assessment and outlook. Journal of Management, 23, 291-374.

Hall, B. \& Murphy, K. (2002). Stock options for undiversified executives. Journal of Accounting and Economics, 33(1), 3-42.

Heath, C, Huddart, S. \& Lang, M. (1999). Psychological factors and stock option exercise. Quarterly Journal of Economics, 114, 601-627. 
Ittner, C.D., Lambert, R.A. \& Larcker, D.F. (2002). The structure and performance consequences of equity grants to employees of new economy firms. Journal of Accounting \& Economics, 34(1), 89128.

Jensen, M.C. and W.H. Meckling (1976), Theory of the firm: managerial behaviour, agency costs and ownership structure, Journal of Financial Economics October, 3(4), 305-360.

Jones, D.C. \& Kato, T. (1995). The productivity effects of employee stock ownership plans and bonuses: Evidence from Japanese panel data. American Economic Review, 85, 3, 391-414.

Kaarsemaker, E. (2006). Employee Ownership and Human resource Management. A Theoretical and Empirical Treatise with a Digression on the Dutch Context. Doctoral Dissertation, Radboud University: Nijmegen

Kaarsemaker, E. \& Poutsma, E. (2006). The Fit of Employee Ownership With Other Human Resource Management Practices: Theoretical and Empirical Suggestions Regarding the Existence of an Ownership High-Performance Work System, or Theory O'. Economic and Industrial Democracy. 27(2), 669-685.

Kalmi, P., Pendleton, A.D. \& Poutsma, E. (2005). Financial participation and Performance: New survey evidence from Europe. Human Resource Management Journal, 15(2), 54-67

Kandel, E. \& Lazear, E.P. (1992). Peer pressure and partnership. Journal of Political Economy, 100(4), 801-817.

Kato, T. \& Morishima, M. (2002). The productivity effects of participatory employment practices: evidence from new Japanese panel data. Industrial Relations. 41(4), 487-520.

Klein, K. (1987). Employee stock ownership and employee attitudes: a test of three models. Journal of Applied Psychology, 72(2), 319-332.

Kraft, K. \& Ugarković, M. (2006). Profit sharing and the financial performance of firms: evidence from Germany. Economic Letters, 92, 333-338.

Kruse, D.L. (1992). Profit sharing and productivity: Microeconomic evidence from the United States. Economic Journal, 102, 24-36.

Kruse, D.L. (1993). Profit Sharing- Does It Make a Difference ? Kalamazoo (Mich, US): W.E. Upjohn Institute for Employment Research.

Kruse, D.L. \& Blasi, J. (1997). Employee ownership, employee attitudes, and firm performance: A review of the evidence. In Lewin, D., Mitchell, D.J.B. and Zaidi, M.A. (eds.), The Human Resource Management Handbook, Part 1, JAI Press (Greenwich, CT, US).

Kruse, D. \& Blasi, J. (2001) Press Release: Study on the Population of Privately-held US Firms with ESOPs. New Brunswick, NJ: Rutgers University School of Management and Labor Relations. (For a summary of the study, see http://www.nceo.org/library/esop_perf.html and for the data tables see http://www.nceo.org/library/esop_perf_tables.html).

Kruse, D.L., Freeman, R.B. \& Blasi, J.R. (Eds) (2010). Shared Capitalism at Work. Employee Ownership, Profit and Gain Sharing, and Broad-Based Stock Options. Chicago: University of Chicago Press, 2010

Lee, Y.-T. (2003). The productivity effects of employee stock-ownership plans: evidence from panel data of Taiwan electronic companies. International Journal of Management, 20(4), 479-489.

Long, R. J. (2000). Employee profit sharing: Consequences and moderators. Relations Industrielles/Industrial Relations, 55(3), 477-504.

Magnan, M. \& St-Onge, S. (2005). The Impact of Profit Sharing on the Performance of Financial Services Firms. Journal of Management Studies, 42(4), 761-792.

Meihuizen, H.E., (2000), Productivity effects of employee stock ownership and employee stock option plans in firms listed on the Amsterdam stock exchange: An empirical analysis, paper presented at the 10th congress of the International Association for the Economics of Participation, Trento (Italy).

McNabb, R., \& Whitfield, K. (1998). The impact of financial participation and employee involvement on financial performance. Scottish Journal of Political Economy, 45(2), 171-187.

Ohkusa, Y \& Ohtake, F. (1997). The Productivity Effects of Information Sharing, Profit Sharing, and ESOPs. Journal of the Japanese and International Economies, 11(3), 385-402. 
Otten, J., Schenk, H. \& Verwer, A. (2008). De code Tabaksblat en de beloning van CEOs in Nederland. Maandblad voor Accountancy en Bedrijfseconomie, 82, 445-453.

Pendleton, A. (2001). Employee ownership, participation and governance: a study of ESOPs in the UK. London and New York: Routledge.

Pendleton, A. (2005). Employee share ownership, employment relationships, and corporate governance. In Harley, B., Hyman, J. and Thompson, P. (eds.) Participation and Democracy at Work: Essays in Honour of Harvie Ramsay. London: Palgrave.

Pendleton, A., Wilson, N. \& Wright, M. (1998). The perception and effects of share ownership: empirical evidence from employee buy-outs. British Journal of Industrial Relations, 36(1), 99-123.

Pérotin, V. \& Robinson, A. (2003). Employee participation in profit and ownership: a review of the issues and evidence. Luxembourg: European Parliament.

Pfeffer, J. (2005). Producing sustainable competitive advantage through the effective management of people. Academy of Management Executive, 19(4), 95-106

Pierce, J.L., Rubenfeld, S.A. \& Morgan, S. (1991).Employee ownership: A conceptual model of process and effects. Academy of Management Review, 16, 121-144.

Pierce, J.L., Kostova, T. \& Dirks, K.T. (2001).Toward a theory of psychological ownership in organizations. Academy of Management Review, 26, 298-310.

Pierce, J.L., Kostova, T. \& Dirks, K.T. (2003). The state of psychological ownership: Integrating and extending a century of research. Review of General Psychology, 7, 84-107.

Poole, M. \& Whitfield, K. (1994). Theories and Evidence on the Growth and Distribution of Profit Sharing and Employee Shareholding Schemes. Human Systems Management, 13(3), 209-220.

Poutsma, E. (2001). Recent Trends in Employee Financial Particiaption in the European Union. Luxembourg: Office for the Official Publications of the European Communities.

Poutsma, E. \& Braam, G. (2012). Financial participation plans and firm financial performance. Evidence from a Dutch longitudinal panel. In: Bryson, A. (ed), Advances in the Economic Analysis of Participatory and Labor-Managed Firms, Emerald Group, 13, 141-185.

Pugh, W.N., Oswald, S.L. \& Jahera, J.S. (2000). The effect of ESOP adoptions on corporate performance: Are there really performance changes? Managerial and Decision Economics, 21, 167-80.

Robinson, A., \& Wilson, N. (2006). Employee financial participation and productivity: an empirical reappraisal. British Journal of Industrial Relations, 44(1), 31-50.

Sesil, J.C., Kruse, D.L. \& Blasi, J.R. (2001). Sharing ownership via employee stock ownership. World Institute for Development Economics Research (WIDER) Discussion Paper 2001/25, United Nations University.

Sesil, J.C. \& Lin, Y.P. (2011). The Impact of Employee Stock Option Adoption and Incidence on Productivity : Evidence from U.S. Panel Data. Industrial relations, 50(3), 514-535.

Sesil, J.C., Kroumova, M., Blasi, J. \& Kruse, D. (2002). Broad-based employee stock options in US 'new economy' firms. British Journal of Industrial Relations, 40, 273-294.

Sesil, J.C. \& Kroumova, M. (2007). Broad-based stock options : before and after the market downturn. International journal of human resource management, 18(8), 1471-1485.

Sweeney, P., McFarlin, D., \& Inderrieden, E. (1990). Using relative deprivation theory to explain satisfaction with income and pay level: A multistudy examination. Academy of Management Journal, 33(2), 423-436.

Trébucq, S. (2004). The effects of ESOPs on performance and risk: evidence from France. Corporate Ownership \& Control, 1(4), 81-93.

Van Der Laan, G., Van Ees, H. \& Van Witteloostuijn, A. (2010). Is Pay related to Performance in The Netherlands? An Analysis of Dutch Executive Compensation, 2002-2006. De Economist 158:123149.

Vroom, V.H. (1964). Work and motivation, New York: Wiley.

Wagner, S., Parker, C. \& Christiansen, N. (2003). Employees that think and act like owners: effects of ownership beliefs and behaviors on organizational effectiveness. Personnel Psychology, 56(4), 847-871. 
Weeden, R., Rosen, C , Carberry, E., \& Rodrick, S. (2001). Current practices in stock option plan design. (2nd ed.). Oakland, CA: National Center for Employee Ownership.

Westphal, J. D., \& Zajac, E. J. (1998). The symbolic management of stockholders: Corporate governance reforms and shareholder reactions. Administrative Science Quarterly, 43(1), 127-153.

Wooldridge, J.M. (2002). Econometric analysis of cross section and panel data. The M.I.T Press, Cambridge, MA. 
Table 1 Summary statistics of sample companies (1992-2009)

Panel A: Company characteristics

\begin{tabular}{|c|c|c|c|c|c|c|}
\hline \multirow{3}{*}{$\begin{array}{l}\text { Industry } \\
\text { (US SIC codes) }\end{array}$} & \multirow{2}{*}{\multicolumn{2}{|c|}{$\begin{array}{l}\text { Number of } \\
\text { companies }\end{array}$}} & \multicolumn{4}{|c|}{ Company size } \\
\hline & & & \multicolumn{2}{|c|}{ No of employees } & \multicolumn{2}{|c|}{ Total assets per employee } \\
\hline & $\mathrm{n}$ & $\%$ & Mean & Std. dev. & Mean & Std. dev. \\
\hline Manufacturing (20-39) & 1147 & 53.3 & 14433 & 3719 & 3004651 & 724846 \\
\hline Trade (50-59) & 363 & 16.9 & 13851 & 3681 & 1913184 & 471730 \\
\hline Services excluding ICT & 375 & 17.4 & 28400 & 6465 & 2407349 & 607616 \\
\hline \multicolumn{7}{|l|}{ (40-49, 70-79 excl. 72-73) } \\
\hline ICT (72-73) & 227 & 10.5 & 2878 & 6268 & 256936 & 65580 \\
\hline Mining (10-17) & 41 & 1.9 & 36059 & 4947 & 52583961 & 7047160 \\
\hline Total & 2153 & 100 & & & & \\
\hline
\end{tabular}

Panel B Companies across year and industry

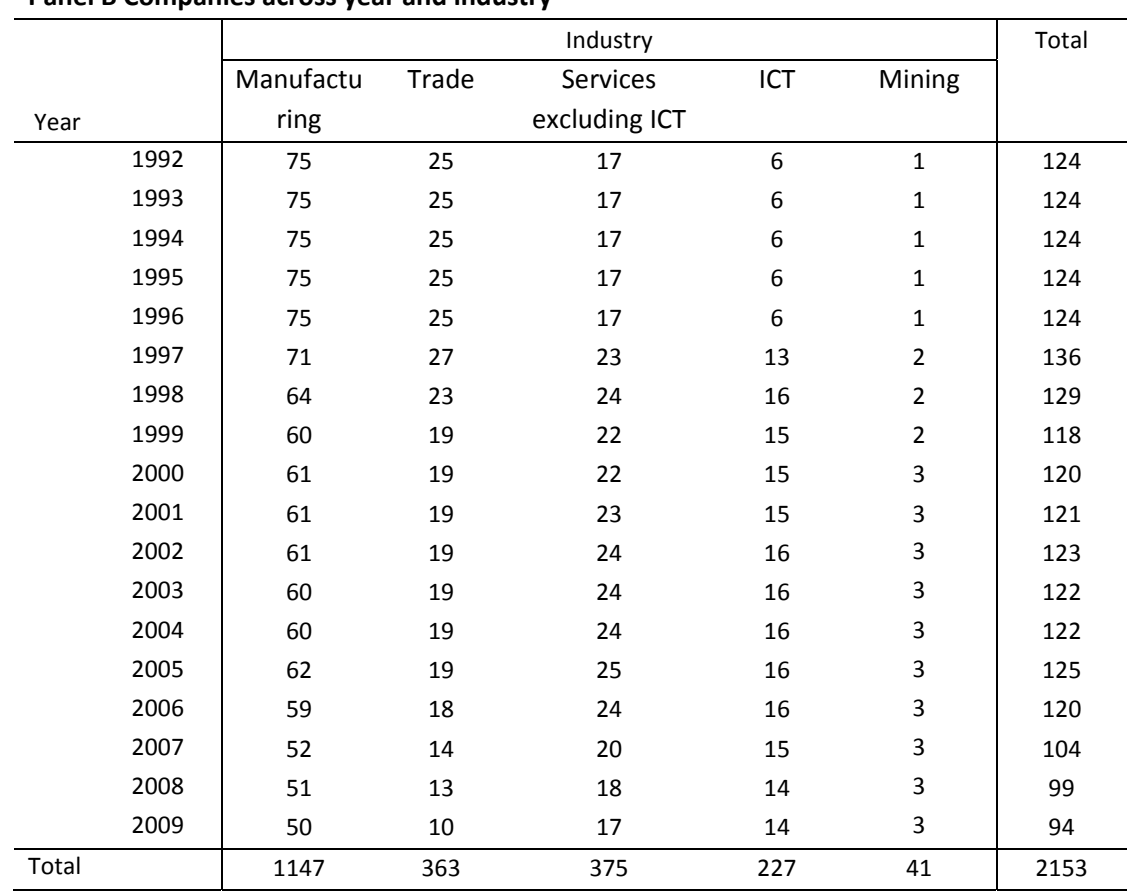


Table 2 Descriptive statistics for broad-based financial participation plans

Panel A: Number of companies that used broad-based share, profit sharing and/or stock option plans across industry in the sample period (1992-2009)

\begin{tabular}{|c|c|c|c|c|c|c|c|}
\hline \multirow{2}{*}{$\begin{array}{l}\text { Combinations } \\
\text { of financial } \\
\text { participation } \\
\text { plans }\end{array}$} & \multicolumn{5}{|c|}{ Industry } & \multicolumn{2}{|c|}{ Total } \\
\hline & $\begin{array}{l}\text { Manu- } \\
\text { factu- } \\
\text { ring }\end{array}$ & Trade & $\begin{array}{l}\text { Services } \\
\text { excluding } \\
\text { ICT }\end{array}$ & ICT & Mining & in \# & in $\%$ \\
\hline No BB FPP & 752 & 291 & 288 & 100 & 19 & 1450 & $67,35 \%$ \\
\hline BB SP & 71 & 7 & 20 & 0 & 0 & 98 & $4,55 \%$ \\
\hline BB PSP & 103 & 22 & 6 & 0 & 0 & 131 & $6,08 \%$ \\
\hline BB OP & 155 & 24 & 45 & 103 & 4 & 331 & $15,37 \%$ \\
\hline BB SP \& PSP & 31 & 17 & 8 & 0 & 10 & 66 & $3,07 \%$ \\
\hline BB OP \& PSP & 22 & 0 & 2 & 9 & 0 & 33 & $1,53 \%$ \\
\hline BB SP \& OP & 9 & 2 & 6 & 13 & 8 & 38 & $1,76 \%$ \\
\hline $\begin{array}{l}\text { BB SP \&PSP \& } \\
\text { OP }\end{array}$ & 4 & 0 & 0 & 2 & 0 & 6 & $0,28 \%$ \\
\hline Total in \# & 1147 & 363 & 375 & 227 & 41 & 2153 & $100,00 \%$ \\
\hline in $\%$ & $53,93 \%$ & $16,70 \%$ & $17,10 \%$ & $10,42 \%$ & $1,85 \%$ & $100,00 \%$ & \\
\hline
\end{tabular}

Explanation

No BB FPP = Absence of any type of broad-based financial participation plan

$B B S P=$ Broad-based share plans but no broad-based profit sharing and option plans

$B B P S P=$ Broad-based profit sharing plans but no broad-based share and option plans

$\mathrm{BB} O \mathrm{OP}=\mathrm{Broad}$-based option plans but no broad-based share and profit sharing plans

BB SP\& PSP = Combinations of broad-based share and profit sharing plans but no broad-

based option plans

BB PSP \& OP = Combinations of broad-based profit sharing and option plans but no broad-

based share plans

BB SP \& OP = Combinations of broad-based share and option plans but no broad-based profit

sharing plans

BB SP \& PSP \& OP = Combinations of broad-based share, profit sharing and option plans

Panel B: Number of companies that used broad-based share, profit sharing and/or stock option plans across use (or no use) of other broad-based financial participation plans in the sample period (1992-2009)

\begin{tabular}{lcccccc}
\hline & \multicolumn{2}{c}{ BB PSP } & \multicolumn{2}{c}{ No BB PSP } & \multicolumn{1}{c}{ (Sub) total } \\
\cline { 2 - 7 } & BB OP & No BB OP & BB OP & No BB OP & in \# & in \% \\
\hline BB SP & 6 & 66 & 38 & 98 & 208 & $9,66 \%$ \\
No BB SP & 33 & 131 & 331 & 1450 & 1945 & $90,34 \%$ \\
\hline (sub) total in \# & 39 & 197 & 369 & 1548 & 2153 & $100,00 \%$ \\
in \% & $1,81 \%$ & $9,15 \%$ & $17,14 \%$ & $71,90 \%$ & $100,00 \%$ & \\
\hline BB SP= Broad-based share plans & & & & & \\
No BB SP= absence of broad-based share plans & & & & \\
BB PSP= Broad-based profit sharing plans & & & & \\
No BB PSP= absence of broad-based profit sharing plans \\
BB OP = Broad-based option plans \\
No BB OP= absence of broad-based option plans
\end{tabular}


Panel C: Number of companies adopted and dropped share, profit sharing and/or stock option plans in the sample period (1992-2009)

Financial participation plans

\begin{tabular}{lccc} 
& \multicolumn{3}{c}{ Type of financial participation plan } \\
\cline { 2 - 4 } & Shares & $\begin{array}{c}\text { Profit } \\
\text { sharing }\end{array}$ \\
\hline Adoption of broad-based financial participation plan & 18 & 28 & 11 \\
Dropping of broad-based financial participation plan & 9 & 20 & 19 \\
Change from narrow to broad-based financial participation plan & 6 & 0 & 16 \\
Change from broad to narrow-based financial participation plan & 7 & 0 & 17 \\
Adoption of narrow-based financial participation plan & 58 & 7 & 58 \\
Dropping of narrow-based financial participation plan & 18 & 3 & 41 \\
No change & 2037 & 2156 & 1991 \\
\hline Total & 2153 & 2153 & 2153 \\
\hline
\end{tabular}




\begin{tabular}{|c|c|c|c|c|c|}
\hline \multicolumn{6}{|l|}{$\begin{array}{l}\text { Table } 3 \text { Regression models } \\
\text { Panel data regression of finan }\end{array}$} \\
\hline \multicolumn{6}{|c|}{ 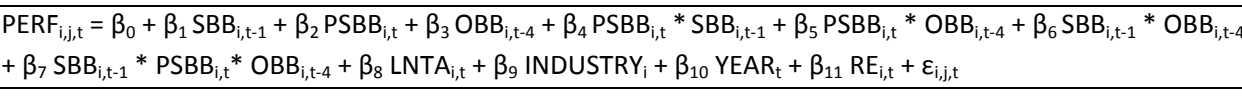 } \\
\hline \multirow[t]{3}{*}{ Independent variables } & \multicolumn{5}{|c|}{ Dependent variables } \\
\hline & \multicolumn{3}{|c|}{ Accounting \& Market-based } & \multicolumn{2}{|c|}{ Market-based } \\
\hline & EPS & SEPS & TOBIN Q & DY & TSR \\
\hline \multirow[t]{2}{*}{$\mathrm{SBB}_{\mathrm{i}, \mathrm{-1}}[\mathrm{H} 1]$} & $0.499 *$ & $-0.070^{*}$ & $0.108^{*}$ & $0.395^{*}$ & $0.412^{*}$ \\
\hline & $(1.44)$ & $(-1.35)$ & $(1.38)$ & (1.34) & $(1.29)$ \\
\hline \multirow[t]{2}{*}{$\mathrm{PSBB}_{i, t}[\mathrm{H} 2]$} & $0.760 * *$ & 0.054 & 0.023 & $0.385^{*}$ & $0.585^{*}$ \\
\hline & $(2.45)$ & $(1.07)$ & $(0.32)$ & $(1.36)$ & $(1.75)$ \\
\hline \multirow[t]{2}{*}{$\mathrm{OBB}_{i, \mathrm{t}-4}[\mathrm{H} 3]$} & -0.098 & $-0.084 * *$ & -0.014 & -0.009 & $0.357^{*}$ \\
\hline & $(-0.40)$ & $(-2.03)$ & $(-0.24)$ & $(-0.04)$ & $(1.40)$ \\
\hline \multirow[t]{2}{*}{$\mathrm{SBB}_{\mathrm{i}, \mathrm{t}-1} * \mathrm{PSBB}_{\mathrm{i}, \mathrm{t}}[\mathrm{H} 4 \mathrm{a}]$} & 0.120 & $0.234^{* *}$ & 0.071 & $0.312^{*}$ & 0.216 \\
\hline & $(0.20)$ & $(2.50)$ & $(0.52)$ & $(1.59)$ & $(0.36)$ \\
\hline \multirow[t]{2}{*}{$\mathrm{PSBB}_{i, t} * \mathrm{OBB}_{\mathrm{i}, \mathrm{t}-4}[\mathrm{H} 4 \mathrm{~b}]$} & -0.797 & -0.097 & $0.724^{* * *}$ & -0.815 & 0.904 \\
\hline & $(-1.09)$ & $(-0.84)$ & $(4.30)$ & $(-1.26)$ & $(1.21)$ \\
\hline \multirow[t]{2}{*}{$\mathrm{SBB}_{\mathrm{i}, \mathrm{t}-1} * \mathrm{OBB}_{\mathrm{i}, \mathrm{t}-4}[\mathrm{H} 4 \mathrm{c}]$} & $-1.792^{* * *}$ & $-0.136^{*}$ & $-0.225^{*}$ & $0.102^{* *}$ & $0.138^{* *}$ \\
\hline & $(-3.03)$ & $(-1.61)$ & $(-1.75)$ & $(2.10)$ & $(2.50)$ \\
\hline \multirow[t]{2}{*}{$\mathrm{SBB}_{\mathrm{i}, \mathrm{t}-1} * \mathrm{PSBB}_{\mathrm{i}, \mathrm{t}} * \mathrm{OBB}_{\mathrm{i}, \mathrm{t}-\mathrm{4}}[\mathrm{H} 4 \mathrm{~d}]$} & $0.245^{*}$ & -0.167 & $-0.766 * * *$ & -0.177 & 0.170 \\
\hline & $(1.88)$ & $(-0.88)$ & $(-2.70)$ & $(-0.16)$ & $(1.35)$ \\
\hline \multirow[t]{2}{*}{ LNTA $_{i, t}$} & $1.410^{* *}$ & $0.180^{* * *}$ & $-0.050 * * *$ & $0.105^{*}$ & 0.007 \\
\hline & $(2.53)$ & $(7.61)$ & $(-2.90)$ & $(1.53)$ & $(0.09)$ \\
\hline Industry $^{1}$ & Y & Y & Y & Y & Y \\
\hline Year $^{1}$ & Y & Y & Y & Y & Y \\
\hline Random effects $^{1}$ & Y & Y & Y & Y & Y \\
\hline \multirow[t]{2}{*}{ Intercept } & -0.116 & 0.235 & $1.673^{* *}$ & 1.132 & $2.630 * * *$ \\
\hline & $(-0.20)$ & (1.08) & $(2.21)$ & (1.24) & $(2.62)$ \\
\hline Wald $-\chi^{2}$ & $116.60^{* * *}$ & $238.45^{* * *}$ & $511.72^{* * *}$ & $77.34^{* * *}$ & $116.28^{* * *}$ \\
\hline $\mathrm{N}$ & 925 & 924 & 927 & 925 & 912 \\
\hline \multicolumn{6}{|c|}{ 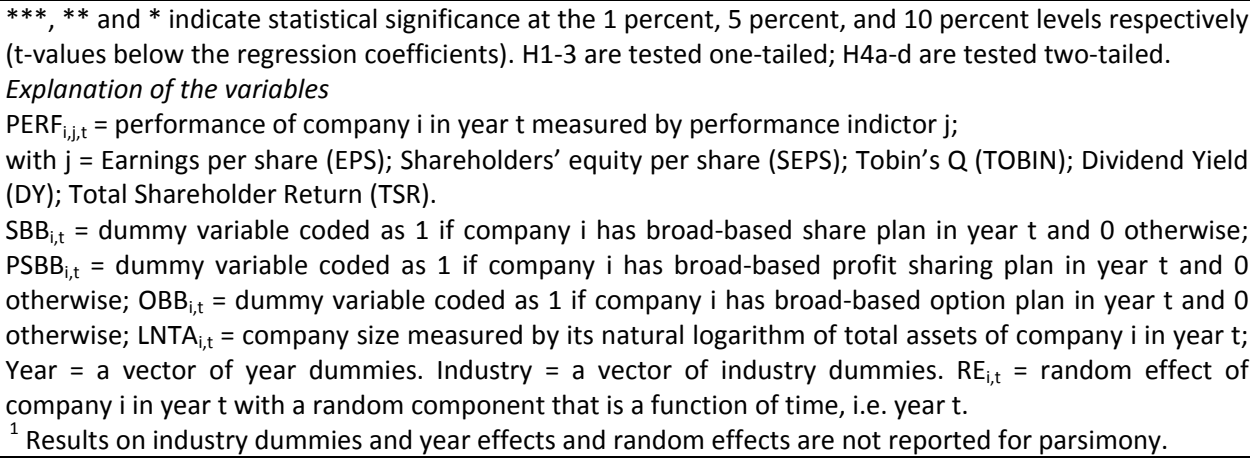 } \\
\hline
\end{tabular}


